\title{
Procrastination and Work Productivity of Academic Staff: Implications to the Institution
}

\section{OPEN ACCESS}

Manuscript ID:

ASH-2021-09014068

Volume: 9

Issue: 1

Month: July

Year: 2021

P-ISSN: 2321-788X

E-ISSN: 2582-0397

Received: 29.04 .2021

Accepted: 07.06.2021

Published: 01.07.2021

Citation:

Asio, John Mark R.

"Procrastination and Work Productivity of Academic Staff: Implications to the Institution." Shanlax International Journal of Arts, Science and Humanities, vol. 9, no. 1 , 2021, pp. 46-53.

DOI:

https://doi.org/10.34293/ sijash.v9i1.4068

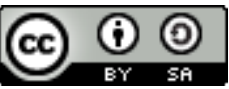

This work is licensed under a Creative Commons Attribution-ShareAlike 4.0 International License

\author{
John Mark R. Asio \\ Gordon College, Olongapo City, Philippines \\ D https://orcid.org/0000-0002-6096-4595
}

\begin{abstract}
Procrastination in the academic institution is not new since it prevails from students even to staff. This might create problems, especially in the individual's output. This study analyzed the relationship, procrastination level, and the work productivity of academic staff from a tertiary education institution in Central Luzon, Philippines. Using a convenience sampling technique, 70 academic staff took part in the survey. This study used a descriptive-correlational design with an adapted questionnaire from McCloskey (2011) and Buuri (2015) as an instrument. For the statistical analysis, the study used SPSS 23 to analyze the gathered data. The study found that the academic staff "often" subject themselves to procrastination, and they "agree" that they are productive in their work. There were significant differences found in the procrastination level and work productivity of the academic staff when grouped according to sex, civil status, and years in service. In terms of relationship, the study confirmed a low direct relationship between the level of procrastination and work productivity of the academic staff. Based on the aforementioned results, the researcher provided some implications for the institution to consider.
\end{abstract}

Keywords: Procrastination, Work productivity, Academic staff, Tertiary education institution, Correlation study, Implications

\section{Introduction}

Working in an academic institution is challenging because of the trifocal function staff must adhere to. This function includes instruction, research, and community extension. Thus, with such an amount of work, individuals turn to procrastinate at some point. Khattak and Ilyas (2017) showed in their study the leading causes of procrastination in the workplace and provided some essential psychological solutions for it. But first, let us define procrastination. McCloskey and Scielzo (2015) defined procrastination as a unique outlet of procrastinatory tendencies. It hinders organizational processes and the delivery of basic resources and services. Some studies tried to remedy the prevalence of procrastination (Richardson, 2018; Teng \& Sun, 2019). The academic institution has a great deal of molding the future of the young generation. Therefore, the academic staff or employees must produce the output for the day to meet the daily quota of work. An article mentioned that procrastination harms performance (Klingsieck, 2013). We cannot argue more. This is the principal reason this study saw if such a notion also prevails in an academic setting. Since the current research is in a tertiary education institution, it would be beneficial for both the organization and the employees to see whether the variables involved in this study persist to some extent.

The main aim of this study is to analyze the relationship, procrastination level, and work productivity of academic staff from a tertiary education institution. These concepts have a great impact on the educational service and how do they serve as leverage to satisfy both ends of the rope, the students, and the organization. 
The researcher intends to add yet another valuable reference for the institution, administrator, academicians, and future researchers. This study will also become a foundation of a simple yet meaningful discovery of new ideas which leads to the development of a more pronounced human resource management soon.

\section{Literature Review}

Procrastination is a global phenomenon which plagues organization. Its causes vary from one setting to another. We link this phenomenon to different human resource ideas and concepts. A research article associated self-efficacy with passive and active procrastination (Hicks \& Storey, 2015). Another article showed the relationship between procrastination and burnout (Hall et al., 2019). Procrastination relates also to personal aspects of life like the study of Ferrari and Landreth (Ferrari \& Landreth, 2014), wherein the exposed rural procrastinators narrate life challenges in their home, family lives, and in their work settings. From another perspective, a study set a distinct point of perspective in their study, which showed an association between procrastination, agreeableness, conscientiousness, and neuroticism in the workplace (Avnion \& Zibenberg, 2018). While procrastination has negative effects on exclusive aspects of the organizational process, Cadena et al., (2011), tested to compete with procrastination, reveal improved worker satisfaction, and minimized levels. As mentioned earlier, procrastination has a restricting effect which leads to performance decline (Aknanejhad $\&$ Ghahari, 2016). Organizations try to devise ways to decrease or prevent procrastination. A particular study devised an application to minimize employees' procrastination rate (Teng \& Sun 2019). Another study tried to reduce procrastination by balancing the schedule (Richardson, 2018) A different article emphasized the position of having an appropriate fit between employment settings and employees (Metin et al., 2018).

In the workplace, it comprises different employees or staff. Therefore, there is this prevalence of diversity, especially in academic institutions. This will produce certain types of relationship which affect the productivity of an individual. A particular study mentioned that there are some organizational factors more particular, the level of self-sacrifice, that affects productivity (Battaglio \& French, 2016). Productivity concepts apply to any type of workplace and conditions. A research article showed that satisfaction with non-material job attributes affects perceived job productivity (Taylor, et al., 2013). This finding seems very interesting since people value money more than anything else. Another study also concluded that employee productivity in the public sector appears useful for productive units (Corsi, \& D'Ippolito, 2013). There are also some negative perspectives about productivity. For instance, neglecting basic work affects the sense of selfefficacy of individuals (Siltala, 2013). To add, another study showed that stock plans need other methods to motivate employees to take part (Pendleton \& Robinson, 2010). Participation among employees or staff is indeed helpful in the organization to prosper, especially in the academic institution. This is so since the organization or institution provides certain goals that need attainment in the end. In this context, some selected HRD sub-systems found selected management styles that impact HR effectiveness (Jain \& Prekumar, 2011).

There are certain relationships and associations between the level of procrastination and work productivity among employees. A research article recognized procrastination as a phenomenon that involves negative outcomes about performance and subjective well-being (Klingsieck, 2013). Another research paper also displayed a negative association between spirituality-based lifestyle and procrastination (Akbarnejhad, \& Ghahari, 2016). The same negative relationship between performance in the workplace and procrastination is observed in another study (Metin et al., 2018) To add, top levels of procrastination associates with some demographic profiles (Nguyen et al., 2013). Also, procrastinating is conduct that leads to wasted time, poor performance, and increased stress (Beheshtifar et al., 2011). This idea is supported by Stephen et al., (2011) wherein procrastination can harm both individual and organizational productivity. Another study also mentioned some effective organizational factors in procrastination (Azimi, \& Ajalli, 2017). 
Based on the following elaborations and discussions from previous pieces of literature, there is no singular context that focuses on the current study's perspective. Also, there was no particular study that dwells on the idea locally. With this in mind, the researcher pursued such a study.

\section{Materials and Methods Research Design}

This study used a descriptive-correlational research design with the survey questionnaire as the principal instrument in gathering valuable data. The study aims to analyze the academic staffs' level of procrastination and work productivity. Since the researcher wants to discover a relationship between the two mentioned variables thus, a descriptivecorrelation technique is suitable for the job.

\section{Research Sample}

70 respondents took part in the survey using a convenience sampling technique. Since the researcher also works in the same academic institution, that is why such sampling technique applies. All the respondents in the study were bona fide academic staff from a tertiary education institution in Central Luzon, Philippines. They work in the same institution as the researcher during the survey administration. The criterion for inclusion includes an individual working in the academic institution for at least a year, regardless of the status of employment excluding the part-time ones.

\section{Research Instrument}

This study adapted and modified the General Procrastination Scale of McCloskey (2011) which comprises 20 statements and Employee Productivity by Buuri (2015) that comprises 11 statements that tackle productivity. The instrument underwent reliability and validity tests using Cronbach's Alpha and the overall result of the reliability test was .81 , which is better than the benchmark score of .70 for the acceptability of the instrument. The researcher also pilot tested the instrument with the students. This is to test its accuracy and understandability of the items before the actual survey administration.

\section{Research Data Analysis}

In this study, the researcher used weighted mean for the descriptions per topic area, t-test, and ANOVA for the significant differences of the means of the responses and Pearson-r for the relationship between the procrastination level and work productivity of the academic staff. With the use of SPSS 23, the researcher tallied, tabulated, statistically analyzed, and interpreted. The researcher also patterned the values assigned to describe the procrastination level and work productivity of the academic staff after a 4-point Likert Scaling.

\section{Results and Discussion}

This study aims to analyze the relationship, procrastination level, and work productivity of academic staff from a tertiary education institution. After tallying, tabulating, and statistical analysis, the study presented the results with the succeeding tables below.

Table 1: Procrastination Level of the Academic

\begin{tabular}{|l|c|c|}
\hline \multicolumn{1}{|c|}{ Statement } & Mean & Interpretation \\
\hline $\begin{array}{l}\text { I often find myself } \\
\text { performing tasks that I had } \\
\text { intended to do days before }\end{array}$ & 3.00 & Often \\
\hline $\begin{array}{l}\text { I intend to do a task until } \\
\text { just before they are to be } \\
\text { handed in }\end{array}$ & 2.86 & Often \\
\hline $\begin{array}{l}\text { When I am finished with a } \\
\text { library book, I return it right } \\
\text { away regardless of the date } \\
\text { it's due }\end{array}$ & 3.06 & Often \\
\hline $\begin{array}{l}\text { When it is time to get up in } \\
\text { the morning I most often get } \\
\text { right out of bed }\end{array}$ & 3.00 & Often \\
\hline $\begin{array}{l}\text { A letter may sit for days } \\
\text { after I write it before } \\
\text { mailing it }\end{array}$ & 2.30 & Sometimes \\
\hline $\begin{array}{l}\text { I generally return phone } \\
\text { calls promptly }\end{array}$ & 2.89 & Often \\
\hline $\begin{array}{l}\text { Even with jobs that require } \\
\text { little else except sitting } \\
\text { down and doing them, I find } \\
\text { they seldom get done for } \\
\text { days }\end{array}$ & 2.56 & Often \\
\hline
\end{tabular}


SHANLAX

International Journal of Arts, Science and Humanities

\begin{tabular}{|c|c|c|}
\hline $\begin{array}{l}\text { I usually make decisions as } \\
\text { soon as possible }\end{array}$ & 3.17 & Often \\
\hline $\begin{array}{l}\text { I generally delay before } \\
\text { starting on work I have to do }\end{array}$ & 2.29 & Sometimes \\
\hline $\begin{array}{l}\text { I usually have to rush to } \\
\text { complete a task on time }\end{array}$ & 2.44 & Sometimes \\
\hline $\begin{array}{l}\text { When preparing to go out, } \\
\text { I am seldom caught having } \\
\text { to do something at the last } \\
\text { minute }\end{array}$ & 2.40 & Sometimes \\
\hline $\begin{array}{l}\text { In preparing for some } \\
\text { deadlines, I often waste time } \\
\text { by doing other things }\end{array}$ & 2.27 & Sometimes \\
\hline $\begin{array}{l}\text { I prefer to leave early for an } \\
\text { appointment }\end{array}$ & 2.86 & Often \\
\hline $\begin{array}{l}\text { I usually start a job shortly } \\
\text { after it is assigned }\end{array}$ & 2.81 & Often \\
\hline $\begin{array}{l}\text { I often have a duty finished } \\
\text { sooner than necessary }\end{array}$ & 2.84 & Often \\
\hline $\begin{array}{l}\text { I always seem to end up } \\
\text { shopping for birthday or } \\
\text { Christmas gifts at the last } \\
\text { minute }\end{array}$ & 2.53 & Often \\
\hline $\begin{array}{l}\text { I usually buy even an } \\
\text { essential item at the last } \\
\text { minute }\end{array}$ & 2.47 & Sometimes \\
\hline $\begin{array}{l}\text { I usually accomplish all the } \\
\text { things I plan to do in a day }\end{array}$ & 2.96 & Often \\
\hline $\begin{array}{l}\text { I am continually saying "I'll } \\
\text { do it tomorrow" }\end{array}$ & 2.20 & Sometimes \\
\hline $\begin{array}{l}\text { I usually take care of all the } \\
\text { tasks I have to do before I } \\
\text { settle down and relax for the } \\
\text { evening }\end{array}$ & 3.17 & Often \\
\hline Over-all Mean & 2.70 & Often \\
\hline
\end{tabular}

Legend: $1.00-1.49=$ Seldom; $1.50-2.49=$ Sometimes;

$$
\text { 2.50-3.49= Often; 3.50-4.00 = Always }
$$

Table 1 above shows the prevalence of procrastination among the academic staff. As observed, statements number 8 and 20 got the highest mean score of 3.17 that has a corresponding interpretation of "often" on the Likert scale. Statement number 19 got the lowest mean score with 2.18, which means "sometimes" in the Likert Scale. The overall mean score is 2.70 and interpreted as "often" on the Likert scale. This only shows that the employees are guilty of procrastinating in their work.
Table 2: Work Productivity of the Academic Staff

\begin{tabular}{|l|c|c|}
\hline \multicolumn{1}{|c|}{ Statement } & Mean & Interpretation \\
\hline $\begin{array}{l}\text { Academic staff's quality } \\
\text { of work improves over } \\
\text { time }\end{array}$ & 3.04 & Agree \\
\hline $\begin{array}{l}\text { Academic staff can deliver } \\
\text { within the set deadlines }\end{array}$ & 3.07 & Agree \\
\hline $\begin{array}{l}\text { The academic staff has } \\
\text { steadily increased their } \\
\text { output }\end{array}$ & 3.04 & Agree \\
\hline $\begin{array}{l}\text { Academic staff can deliver } \\
\text { under less than perfect } \\
\text { conditions }\end{array}$ & 2.79 & Agree \\
\hline $\begin{array}{l}\text { Over time academic staff } \\
\text { has been able to reduce } \\
\text { service cycle time }\end{array}$ & 2.70 & Agree \\
\hline $\begin{array}{l}\text { Academic staffs provide } \\
\text { suggestions to enhance } \\
\text { their service delivery }\end{array}$ & 3.04 & Agree \\
\hline $\begin{array}{l}\text { Academic staffs are } \\
\text { eager to learn ways of } \\
\text { making themselves more } \\
\text { productive }\end{array}$ & 3.26 & Agree \\
\hline $\begin{array}{l}\text { Over time academic staff } \\
\text { has increased customer } \\
\text { satisfaction with the } \\
\text { quality service delivered }\end{array}$ & 3.04 & Agree \\
\hline $\begin{array}{l}\text { Academic staff can } \\
\text { generate more than } \\
\text { an hours' worth of } \\
\text { productivity each hour }\end{array}$ & 3.04 & Agree \\
\hline $\begin{array}{l}\text { Academic staffs have a } \\
\text { sense of what to do and } \\
\text { when to do it }\end{array}$ & 3.09 & Agree \\
\hline $\begin{array}{l}\text { Academic staffs are eager } \\
\text { to maximize themselves to } \\
\text { be more productive }\end{array}$ & 3.21 & $\begin{array}{l}\text { Academic staff can } \\
\text { attentify and give top to top priorities }\end{array}$ \\
\hline Over-all Mean & 3.21 & Agree \\
\hline
\end{tabular}

Legend: $1.00-1.49=$ Seldom; $1.50-2.49=$ Sometimes;

$$
\text { 2.50-3.49 = Often; 3.50-4.00 = Always }
$$

Table 2 above shows the work productivity of the academic staff. As seen, the statement that got the highest mean score is item number 7 with a score of 3.26 with an interpretation of "agree" on the Likert 
scale. However, statement 5 got the lowest mean score with 2.70 , still interpreted as "agree" on the Likert scale. The overall mean is 3.05 with a Likert interpretation of "agree". This only shows that the respondents have high productivity perceptions.

Table 3: Significant Difference in the Procrastination Level and Work Productivity of Academic Staff

\begin{tabular}{|c|c|c|c|c|c|c|}
\hline \multirow{2}{*}{} & \multicolumn{3}{|c|}{ Procrastination level } & \multicolumn{2}{|c|}{ Work Productivity } \\
\cline { 2 - 6 } & $\mathbf{M}$ & SD & $\begin{array}{c}\text { t- } \\
\text { value }\end{array}$ & M & SD & $\begin{array}{c}\text { t- } \\
\text { value }\end{array}$ \\
\hline $\begin{array}{c}\text { Male } \\
(\mathrm{n}=41)\end{array}$ & 2.76 & 0.45 & & 3.20 & 0.54 & \multirow{2}{*}{1.307} \\
\cline { 1 - 5 } $\begin{array}{c}\text { Female } \\
(\mathrm{n}=29)\end{array}$ & 2.62 & 0.40 & & 2.83 & 0.59 & \\
\hline
\end{tabular}

Table 3 represents the t-test for the significant difference in procrastination level and the work productivity of academic staff when grouped according to sex. As observed, there is no significant finding to the procrastination level of the academic staffs since the weighted means of male $(\mathrm{M}=2.76$; $\mathrm{SD}=0.45)$ and female $(\mathrm{M}=2.62 ; \mathrm{SD}=0.40)$ yielded a t-value of 1.307 which corresponds to a probability value of .196 which is not enough to suffice the alpha significance level of .05 . This means that regardless of the sex of the academic staff, the prevalence of procrastination does not vary that much in the workplace. In terms of work productivity, there is a significant difference observed in the academic staff response. Since the t-value was 2.685 which corresponds to a p-value of .010 is lower than the alpha level of significance of .05 . This evidence shows that the sex of the academic staff affects the work productivity of academic staff.

Table 4: ANOVA in the Procrastination Level and Work Productivity of the Academic Staff

\begin{tabular}{|c|c|c|}
\hline Variables & $\begin{array}{c}\text { Procrastination } \\
\text { Level }\end{array}$ & $\begin{array}{c}\text { Work } \\
\text { Productivity }\end{array}$ \\
\hline \multirow{2}{*}{ Age } & 0.206 & 2.489 \\
$(.892)$ & $(.068)$ \\
\hline \multirow{2}{*}{ Civil Status } & $3.171^{*}$ & $6.363^{*}$ \\
& $(.048)$ & $(.003)$ \\
\hline \multirow{2}{*}{ Years in Service } & 0.442 & $3.558^{*}$ \\
& $(.644)$ & $(.034)$ \\
\hline
\end{tabular}

$* \mathrm{p}<.05$
Table 4 shows the Analysis of Variance (ANOVA) for the significant difference in the procrastination level and work productivity of academic staff when grouped according to age, civil status, and years in service. There is a significant difference in the procrastination level of the academic staff in terms of civil status since it yielded an F-value of 3.171 with a probability value of 0.048 which is significant at the alpha significance level of .05. In terms of age and years in service, they did not yield substantial evidence of difference since their F-values are 0.206 and 0.442 with p-values of .892 and .644 . This means that civil status can influence occurring procrastination in the workplace. However, age and years in service do not give that much of a difference.

For the productivity of the respondent, we observe significant evidence of a difference in terms of civil status and years in service since they got F-values of 6.363 and 3.558. These correspond to $p$-values of .003 and .034 at the same time. Their F-values are significant at the alpha level of significance of .05 . Age did not yield a substantial degree of difference since the F-value is 2.489 with a p-value of .068 is higher than the alpha significance level of .05 . This means that civil status and years in service can influence the productivity of an employee. However, age is not a factor in determining the productivity of an individual.

Table 5: Correlation Matrix Between the Procrastination Level and Work Productivity of Academic Staff

\begin{tabular}{|c|l|c|c|}
\hline & & 1 & 2 \\
\hline \multirow{3}{*}{$\begin{array}{c}\text { Procrastination } \\
\text { Level }\end{array}$} & Pearson $\mathrm{r}$ & & $.274^{*}$ \\
\cline { 2 - 2 } & \multicolumn{2}{|c|}{1} & .022 \\
\cline { 2 - 2 } $\begin{array}{c}\text { Sig. (2-tailed) } \\
\text { Work }\end{array}$ & $\mathrm{N}$ & & 70 \\
\hline \multirow{2}{*}{\begin{tabular}{c} 
Productivity \\
\cline { 2 - 2 }
\end{tabular}} & Pearson $\mathrm{r}$ & $.274^{*}$ & \multirow{2}{*}{1} \\
\cline { 2 - 3 } & Sig. (2-tailed) & .022 & \\
\cline { 2 - 3 } & $\mathrm{N}$ & 70 & \\
\hline
\end{tabular}

$* \mathrm{p}<.05$

Table 5 shows the relationships between the academic staff's procrastination level and work productivity. As seen from the table, a low-direct relationship between procrastination level and work productivity of the academic staff. Since the study found the Pearson r-value of .274 which is significant at .05 Alpha level of significance. This only means 
that when procrastination happens, it affects work productivity at the same time.

\section{Discussion}

The principal aim of this study is to analyze the relationship, procrastination level, and work productivity of academic staff in a tertiary education institution in Central Luzon, Philippines. The study found some interesting results that might contribute to the ever-growing literature regarding procrastination and work productivity.

As observed from the result of the survey, academic staff procrastinate in their line of work. This result coincides with the ideas of an article that provided a conclusion on the overview of procrastination regarding its presence and its implications (Wilson \& Nguyen, 2012). Another related study showed that respondents with high procrastination rates are pessimistic and negative about past events (Zabelina et al., 2018). The result of the work productivity survey also confirmed a positive response. The result of the study is in congruence with the ideas of Abbasi and Alghamdi (2015), procrastination is unavoidable, and people suffer at changing degrees with adverse consequences. In relation further, Kovacs et al., (2019) introduced that productivity behavior change systems help us decrease time on unproductive activities.

The present study also subjected the data through different statistical treatment and found some notable results. Although the study posted no significant difference in the procrastination of academic staff, their work productivity however yielded a noteworthy result. The result, however, is in contrast with the findings of Prem et al., (2018) wherein they showed the link of work features to workplace procrastination. Some other studies pointed out that women procrastinate less than men, giving women an employment advantage (Nguyen et al., 2013; Beutel et al., 2016). Also, an article showed that different personality traits play a role in the two forms of procrastination in gender groups (Zhou, 2020). Other contradicting studies include that of Beutel et al., (2016) wherein their group found that procrastination is highest in the youngest cohort (age 14 to 29 years). Another article also mentioned that younger adults procrastinate more than middle-aged and older-aged adults (Nomura \& Ferrari, 2018). They also found out that being single or had no children delay in doing tasks more than those who did not.

A deeper insight into the study includes the investigation of relationships between procrastination level and work productivity of academic staff. Current study provided significant results. A relationship existed between the two variables. To support the study's result, Cetin and Kumkale (2017) showed that they found a negative relationship between procrastination and task performance.

\section{Conclusion}

Based on the data and information gathered and treated, the researcher concluded on the following ideas. In terms of procrastination level, the academic staff revealed an overall mean of 2.70 which is interpreted as "often" in the Likert Scale. For the work productivity of the academic staff, it yielded an overall mean of 3.07 which is interpreted as "agree" in the Likert Scale. There is no significant difference in procrastination when grouped according to sex. However, we observed significant findings in terms of work productivity when the academic staff is grouped according to sex. Civil status produced a significant result in procrastination, however, age and years in service did not. For the work productivity of the academic staff, we found substantial evidence of differences in civil status and years in service. There is also evidence of a relationship between the procrastination level and the work productivity of the academic staff.

Just like other studies, this one is no exception to its limitations. The first limitation of this study is the setting since it is only done in just one particular institution; it is highly advisable to do it in several academic institutions from a broader perspective. Second, the respondents, since the study was done in a brief amount of time, the number of respondents was not met. Some respondents did not return the survey because of their busy schedules and workload. Last, the method, it is suggested to triangulate the quantitative results with qualitative remarks of other respondents to strengthen the result of the study. Therefore, a mixed form of research design is suggested. 


\section{Implications}

From the results of the study, the researcher provided the following implications for the institution to consider. First, the institution should explore the extent of procrastination in the workplace. This is in coordination with the human resource management office, since they all have the profile of the academic staff and work with the Guidance Counselor for the assessment and intervention. The institution should also organize timely seminars, workshops, and/ or training programs to help minimize procrastination and maximize the productivity of the academic staff. This will also help them promote their professional growth and development at the same time. Intervention programs spearheaded by the guidance office are another suggestion to monitor and intervene with the prevalence of the procrastinatory attitudes and behaviors of the academic staff as necessary. A flexible working schedule is another suggestion, especially for those staff that is needed because of their expertise and skills. This will provide the staff more time with their family and can work more efficiently. It is also important to revisit the institution's vision, mission and goals so that the academic staff should adhere to it together with their commitment, loyalty, and trust. In this way, the staff will not get lost and have a direct line of achieving the output intended for the institution. To promote motivation, exemplary awards and incentive systems should be strengthened and promoted. In this way, their significance in the organization will be recognized and appreciated by the institution, however big or small this achievement may be. Last, it is suggested to replicate this study but in a different perspective or with additional variables to explore more within the realm of procrastination and work productivity.

\section{References}

Abbasi, Irum Saeed, and Nawal G. Alghamdi. "The Prevalence, Predictors, Causes, Treatment, and Implications of Procrastination Behaviors in General, Academic, and Work Setting." International Journal of Psychological Studies, vol. 7, no. 1, 2015.

Akbarnejhad, Hajar, and Shahrbanoo Ghahari. "Relationship between Spirituality-Based
Lifestyle and Procrastination among Employed Women in Iran." Biology and Medicine, vol. 9, no. 1, 2017.

Azimi, Hossein, et al. "Presentation of a Model for Survey of the Effective Factors on Procrastination of Employees in Organizations." International Journal of Management, Accounting and Economics, vol. 4, no. 6, 2017, pp. 675-681.

Battaglio, R. Paul, and P. Edward French. "Public Service Motivation, Public Management Reform, and Organizational Socialization." Public Personnel Management, vol. 45, no. 2, 2016, pp. 123-147.

Beheshtifar, Malikeh, et al. "Effect Procrastination on Work-Related Stress." European Journal of Economics, Finance and Administrative Sciences, no. 38, 2011, pp. 59-64.

Beutel, Manfred E., et al. "Procrastination, Distress and Life Satisfaction across the Age Range - A German Representative Community Study." PLOS ONE, vol. 11, no. 2, 2016.

Cadena, Ximena, et al. "Fighting Procrastination in the Workplace: An Experiment." NBER Working Paper Series, 2011.

Çetin, Olgun Irmak, and Ilknur Kumkale. "The Relation between Procrastination and Task Performance." Journal of Current Researches on Business and Economics, vol. 7, no. 2, 2017, pp. 193-206.

Corsi, Marcella, and Carlo D'Ippoliti. "The Productivity of the Public Sector: A Classical View." PSL Quarterly Review, vol. 66, 2013, pp. 403-434.

Ferrari, Joseph R., and Nicole Landreth. "Guess I am a Procrastinator: Self and Other Perceptions among Rural US Citizens." North American Journal of Psychology, vol. 16, no. 1, 2014.

Hall, Nathan C., et al. "Self-Efficacy, Procrastination, and Burnout in Post-Secondary Faculty: An International Longitudinal Analysis." PLOS ONE, vol. 14, no. 12, 2019.

Hicks, Richard E., and James Storey. "Can Procrastination be Effective? A Study of White-Collar Employees and University Students." International Journal of Business Research, vol. 15, no. 1, 2015, pp. 39-48. 
Jain, Ravindra, and R. Premkumar. "HRD Practices in Indian Organizations and their Impact on 'Productivity' of Human Resources: An Empirical Study." Management and Labour Studies, vol. 36, no. 1, 2011, pp. 5-30.

Khattak, Asmat Nawaz, and Muhammad Ilyas. "Task Procrastination: Overcoming through ReEstablishment of Psychological Association." Journal of Business Strategies, vol. 11, no. 2, 2017, pp. 73-88.

Klingsieck, Katrin B. "Procrastination." European Psychologist, vol. 18, no. 1, 2013, pp. 24-34.

Kovacs, Geza, et al. "Conservation of Procrastination: Do Productivity Interventions Save Time or Just Redistribute it?." Proceedings of the 2019 CHI Conference on Human Factors in Computing Systems, 2019.

McCloskey, Justin, and Shannon Amerilda. "Finally! The Development and Validation of the Academic Procrastination Scale." 2015.

Metin, U. Baran, et al. "Correlates of Procrastination and Performance at Work: The Role of having 'Good Fit."' Journal of Prevention \& Intervention in the Community, vol. 46, no. 3 , 2018, pp. 228-244.

Nguyen, Brenda, et al. "Procrastination's Impact in the Workplace and the Workplace's Impact on Procrastination." International Journal of Selection and Assessment, vol. 21, no. 4, 2013, pp. 388-399.

Nomura, Miki, and Joseph R. Ferrari. "Factor Structure of Japanese Version of the Adult Inventory of Procrastination Scale: Delay Is Not Culture Specific." North American Journal of Psychology, vol. 20, no. 1, 2018, pp. 223-238.

Pearlman-Avnion, Shiri, and Alexander Zibenberg. "Prediction and Job-Related Outcomes of Procrastination in the Workplace." Journal of Prevention \& Intervention in the Community, vol. 46 , no. 3 , 2018, pp. 263-278.
Pendleton, Andrew, and Andrew Robinson. "Employee Stock Ownership, Involvement, and Productivity: An Interaction-Based Approach." ILR Review, vol. 64, no. 1, 2010, pp. 3-29.

Prem, Roman, et al. "Procrastination in Daily Working Life: A Diary Study on Within-Person Processes that Link Work Characteristics to Workplace Procrastination." Frontiers in Psychology, vol. 9, 2018.

Richardson, Anna. "Balanced Scheduling to Reduce Procrastination: Can Scheduling Enjoyable Activities Increase Productivity and Satisfaction?" Student Research Proceedings, vol. 3, no. 1, 2018.

Siltala, Juha. "New Public Management: The Evidence-Based Worst Practice?." Administration \& Society, vol. 45, no. 4, 2013, pp. 468-493.

Stephen, Andrew T., et al. How Being Busy Overcomes Procrastination and Enhances Productivity.

Taylor, Jeannette, et al. "The Influence of Job Attributes and Culture on Job Productivity." Review of Public Personnel Administration, vol. 33, no. 2, 2013, pp. 205-224.

Teng, Felianne, and $\mathrm{Yu}$ Sun. "Devising an Application to Decrease Procrastination." Journal of Computers, vol. 14, no. 3, 2019, pp. 152-160.

Wilson, Brian, and Tuyen Nguyen. "Belonging to Tomorrow: An Overview of Procrastination." International Journal of Psychological Studies, vol. 4, no. 1, 2012.

Zabelina, E., et al. "Time Perspective as a Predictor of Procrastination." Procedia - Social and Behavioral Sciences, vol. 238, 2018.

Zhou, Mingming. "Gender Differences in Procrastination: The Role of Personality Traits." Current Psychology, vol. 39, 2020, pp. 1445-1453.

\section{Author Details}

John Mark R. Asio, Gordon College, Olongapo City, Philippines, Email ID: asio.johnmark@gmail.com 